\title{
Student Centered Learning and Flipped Classroom of Lesson Study: A Case Study in Higher Education
}

\author{
Athika Dwi Wiji Utami ${ }^{1}$, Agung Purnomo ${ }^{2,3}$, Masyitah Noviyanti ${ }^{1}$, \\ Fatkul Anam $^{4}$, Evi Mahsunah ${ }^{1}$ \\ ${ }^{1}$ Universitas Nahdlatul Ulama Sidoarjo, Indonesia \\ ${ }^{2}$ Bina Nusantara Institute of Creative Technology Malang, Indonesia \\ ${ }^{3}$ Universitas Airlangga, Indonesia \\ ${ }^{4}$ Universitas Wijaya Kusuma Surabaya, Indonesia
}

\begin{abstract}
This research aims to uncover the phenomenon that occur in implementing lesson study using Student Center Learning, flipped classroom, and Edmodo by Visual Communication Design study program lecturers of University Nahdlatul Ulama of Sidoarjo, Indonesia. This research approach method is a descriptive qualitative research and case study with Edmodo using observation, interview, and data collection. The process involves allied lecturers in collaboration from starting Plan, Do and See. The results of the study based on the Lewis Lesson Study cycle showed that there were several stages that were not met properly. In Plan activity, the lesson group are not functioning optimally. In the Do activity, the observer lecturer is still fixated on the lecturer's teaching performance. In the See activity, the conversation is limited by explain the phenomena that occur without further discussion about why this happened. While on the selection of Student Center Learning, flipped classroom, and Edmodo as an approach in the lesson study is very helpful for lecturers in improving learning motivation, understanding of knowledge, and good attitude of students towards the material being taught.
\end{abstract}

Key words: Higher Education, Flipped Classroom, Learning

\section{Introduction}

Visual Communication Design (VCD) is a branch of design that studies communication concepts and creative expressions, techniques, and media by utilizing aesthetic components to express messages for the goal of information or the purpose of persuasion that influences behavior [1]. VCD ideally is not only limited to someone who is capable of designing (as a designers) but also as a problem solver, that is, those who are able to design a visual creatively and innovatively so that the message can be sent to the target communicatively, efficiently and effectively. Higher education has the responsibility of providing optimal facilities during the education process. One of them is through lecturers, the educating and learning process in lectures should manage to become a place for students to be able to explore their potential, explore creativity, and not be left behind by developments in the field of VCD.

Lesson Study for Learning Community (LSLC) is a model of fostering the teaching profession through the study of collaborative and continuous learning based on the maxims of collegiality and 
shared learning how to increase the caliber of learning and build learning communities [2]. Lesson Study focuses its strategy on the development of the teaching profession, because improving teacher quality will be strongly correlated with enhancing the quality of learning and students as learning outputs [3]. In Lesson Study, teachers collaborate with fellow lecturers in one group or group of fields of knowledge or across fields of knowledge sharing the teaching experience of each lecture. During the planning and development of lectures, the group of lecturers conducting discussions ranging from planning such as the preparation of lesson plan and teaching materials, classroom management strategies, and learning assessment systems. When teaching, other lecturers become observers who are tasked with observing events during the learning process. After the class over, the group discusses the phenomena that occur during the lecture, the constraints experienced by the students during the learning process, constructive criticism from the observer lecturer, to solutions of the obstacles that can be carried out at the next meeting. So, through the implementation of lesson study, it is expected that lecturers better understand what is experienced by students during the implementation and get solutions for improvement. In the end there was an increase in the quality of teaching of each lecturer.

In this case study, the learning method approaches used are student-centered learning (SCL) and assisted by ICT. SCL approach is a learning approach where students construct and find their own knowledge. In this approach, the lecturer gives students the opportunity to study independently and learn from their friends. Lecturers provide open problems and problems that require critical or creative thinking through collaborative learning. SCL can increase learning motivation, knowledge understanding, and positive attitude towards the material being taught [4]. The model of the SCL in this case study is called small group discussion and cooperative learning Jigsaw. While for learning with ICT assisted, it uses a combination of Flipped Classroom and Edmodo. Flip classroom is a pedagogical model that exchanges lecture sequences with student assignment activities outside the classroom; lectures are held via video recording / streaming and listened outside the classroom while assignments are completed in the classroom. This approach combination is expected to form the independence of students in constructing understanding and knowledge through ICT. Edmodo is one of the social networks intended for teachers and students, lecturers and students, or parents and guardians of students, created for lecturers and students by implementing a more enjoyable learning system [5]. Edmodo is a platform that connects students with lecturers in an organized manner in online lecture activities, ranging from access to assignments, grades, discussions, giving material, and information related to lectures [6].

Education is a lifelong effort to develop one's potential according to community values in order to achieve ultimate life goals. Educational management is useful for building educational ecosystems to achieve educational goals. In the previous learning process, VCD study programs lecturers more likely to frequently apply the lecture and tutorial approaches. Lectures are centered on lecturers so students tend to accept what the lecturer has to say. This results in the lack of independence of students in understanding lecture material, where they attend lectures without preparation of knowledge about lecture material. The VCD study program lecturers of University Nahdlatul Ulama of Sidoarjo, Indonesia are still working independently in carrying out planning lectures, both from determining the material, making material, assessment, and so on. Ideally, a group of lecturers is formed with the same subject area to discuss the planning and implementation of lectures. With this group of lecturers, it is expected that there will be sharing and input in improving lectures. Therefore, this research aims to uncover the phenomenon that occur in implementing lesson study using Student Center Learning, flipped classroom, and Edmodo by Visual Communication Design study program lecturers of University Nahdlatul Ulama of Sidoarjo, Indonesia. 


\section{Research Methods}

This paper presents a case study from the practical experience of LSLC conducted by lecturers of the VCD Study Program at Nahdlatul Ulama University of Sidoarjo (UNUSIDA). This research approach is a descriptive qualitative research using Lesson Study method based on Classroom Action Research. Study Studies are carried out in a series of activities called cycles, consisting of three activities, first Plan (planning), second Do (implementation), and See (reflection) for 3 (three) cycles. In this research, the model lecturer (researcher) collaborates with two lecturers from the same group as observers for these 3 cycles. Observers who are actively involved in the process of planning lectures (Plan), implementing while in class (Do), and reflecting (See) findings during implementation in class. When doing, $D o$, the observer fills in the observation sheet containing questions about the phenomena that occur during lectures. During reflection See, the model and observer lecturer discuss the findings obtained by the teaching observer, the potency of the lecture at the meeting that day, and suggest negative findings to improve the next cycle.

Based on observations and results of implementation, See, the data are analyzed with qualitative descriptive techniques. The results of the data analysis are a description of the lecture process review conducted by the model lecturer, valuable experience found by the observer and model lecturer, and suggestions used by the model lecturer to improve the lecture plan at the next cycle.

The subjects of this study were 142017 A class students of the VCD Study Program, Faculty of Computer Science, UNUSIDA, who programmed Design Psychology courses in the odd semester of the 2018/2019 school year. Before the first meeting the model lecturer had held a class (outside the lecture schedule) to provide an explanation of the syllabus, lecture contract, and course introduction.

\section{Result}

\subsection{The Implementation of Lesson Study Observed}

\subsubsection{Plan}

The Plan stage is attended by model and observers lecturers. That stage is in the form of discussion, starting from the selection of strategies, materials, implementation during class, to assessment.The first stage before entering the lesson study stages (plan-do-see) is to invite a SCL and Lesson Study expert speakers, Dr. Ibrahim, M.Sc. to provide guidance for model and observer lecturers on how to implement the right lesson study and lesson design based on SCL and ICT.

In the first cycle of the Plan stage, the model lecturer conveys plans to conduct lectures in the second cycle with introductory of psychology, the flow of psychology, and an introduction to cognitive psychology. The learning process uses a flipped classroom approach with the small group method discussion / group assisted by Edmodo. Classes are arranged in U-shaped chair formations.

In the second cycle of the Plan stage, the model lecturer presents plans to conduct lectures in the second cycle with Sensation, Perception, and Attention material. This approach still uses the flip classroom with the discussion / small group method assisted by Edmodo. However, when in class after group discussion, the lecturer will make a quiz by giving scrambling questions to be answered by group representatives. Classes are arranged in U-shaped chair formations.

In the third cycle of the Plan stage, the model lecturer submits a plan for conducting lectures with the material Visual Perception Theory. Classes are still in the same grouping as Cycles 1 and 2. The approach uses the flip classroom model with the cooperative learning Jigsaw method assisted by edmodo. Classes are arranged in U-shaped chair formations.

\subsubsection{Do}


In the first cycle, before meeting in class, students are asked to do the pre assignment 1 of summarizing video related material through edmodo. When in class, students are divided into 4 groups (3 - 3 - 3 - 4 students). The lecturer gives a matter of deepening as group discussion material. After the discussion time is over, the lecturer gives the opportunity for group representatives to answer questions from the questions given. The lecturer confirms the correctness of the answer to the question and continues to confirm the answer with an explanation and video. In closing, the lecturer concludes the material and explains what will be discussed at the next meeting.

In the second cycle, before meeting in class, students do pre-assignment 2 through edmodo like cycle 1. When in class, there is a group discussion about the video material that has been given through Edmodo. After the discussion time is over, the lecturer explains to the class that the lecturer will give a quiz in which there are 2 rounds (correct questions score 10 in the first round and a score of 20 in the second round). The lecturer also explained that the group with the highest score would get a reward. In closing, the lecturer confirmed the correctness of the answers to the questions, concluded the material, and explained what would be discussed at the next meeting.

In the third cycle, before meeting in class, students work on pre assignment 3 through edmodo. When in class, the Jigsaw cooperative learning model is applied. The material is represented by 3 videos. Each student per group will get a different video material. Only in group 4 consists of 4 students there were 2 students who received the same video material. During class meetings, students are divided into expert groups and jigsaw groups. The jigsaw group is the original group ie groups 1 to 4 . While the expert group is students with the same video material from all groups gathered in one group, so there will be 3 groups of experts. After the expert group discusses the video material they get, the student returns to each home group (jigsaw). In the home group, each student has the task of explaining to his friends about the material he gets in turn. At the end of the meeting, the lecturer gives a quiz with the provisions that the total scoring is the average of the student's score from assignment 3 and the group's score when meeting in class. In closing, the lecturer confirmed the correctness of the answers to the questions, concluded the material, and explained what would be discussed at the next meeting.

\subsubsection{See}

This cycle focuses on reflection between lesson plans and learning that is applied in class. Model and observer lecturers gather to discuss observer data and field notes during the lesson study. All positive and negative findings are then discussed to find a solution. All inputs are used as input for improvement plans in the next cycle. In cycles 1 to 3 , the see stage is always carried out after the implementation of $D o$.

The results of cycle 1, among others: model lecturer perform improvements to class time management, monitoring on student activities while in class, checking the progress of each group's discussion, giving motivation to students who look passive. Positive findings are using class settings with U-seat chairs because of the cycle 1 is considered effective enough to bring a class that feels more "alive" and variations in class activities make students look more enjoy.

The results of cycle 2, among others: students began to be brave and confident to have an opinion, the classroom atmosphere was more fluid than the first meeting, and scoring in the quiz was very helpful for active opinion. Inputs for the next cycle are model lecturer need to provide an explanation of the quiz rules at the beginning of lecture and besides giving rewards, it is expected that the provision of punishment for the group with the lowest score.

The results of cycle 3, include: the level of enthusiasm and confidence of students in opinion is better than the two previous meetings. However, there was 1 student who was still not confident and passive during the quiz session. The lecturer has checked while the discussion is running so that 
students can be controlled by their discussion activities and the scoring and reward punishment system is a useful experience.

\subsection{The Problem Faced in Lesson Study Implementation}

\subsubsection{Plan}

Based on interviews with model and observer lecturers, the problem faced during the Plan is the limited time available for lecturers to discuss designing classroom management. In addition, the model and observer lecturers's knowledge of lesson study using the SCL approach is still lacking so results at this stage are not very mature. But gradually in the following cycles, this stage has improved in line with the experience of lecturers obtained each cycle.

\subsubsection{Do}

In cycle 1, there are still some students who have not been disciplined in following discussions and working on pre-assignment 1 due to the unfamiliar approach to flip classroom and Edmodo. the number of students who do not gather is quite high. The learning experience with flip classroom and Edmodo is also the first time felt for students. The class situation feels stiff because it is not used to the group system. In the first cycle, the model lecturer was not maximized in managing time so the time for discussion was too long. The observer lecturer is still a bit confused when doing his work in class. They tend to only focus on lecturer performance.

In cycle 2, the strategy used is group discussion and giving a quiz with a reward system for the group with the best score. Students are getting used to the flip classroom system and using edmodo, the number of students not doing pre-assignments is less. At the time of giving the quiz, the atmosphere of the classroom was lively because all groups of students were stimulated to compete to get the best score. But there are still some students who are dominant in their groups while the other members seem to be followers and are passive.

In cycle 3, the strategy used is the jigsaw model where the class is divided into expert groups and jigsaw (origin). When in the expert group, there were still some passive students in the discussion, so when they returned to the jigsaw group, the student had difficulty explaining the questions they got while in the expert group. Compared to the second cycle, in this cycle the activeness of students when competing to answer quiz questions that lecturers provide is much better. Questions are no longer dominated by one student in a group. However, there was 1 student who still did not show his activeness during the quiz session. There are still some students who do not do pre-assignments too, even though the number is lower than the previous cycle.

\subsubsection{See}

The implementation See right after the implementation of the Do, so with the limited time the reflection process is not optimal. The observer lecturer experience in using the SCL approach and blended learning has not been much so that the input provided is less than optimal. In cycle 1, the model and observer lecturers were still confused in carrying out the See stage. But in the next cycle, the discussion was smoother and more conducive as there were many discussions.

\subsection{The Benefits in Lesson Study Implementation}

Based on the results of the interviews, the model lecturer felt many benefits from the implementation of this program, including better preparation both in terms of material and implementation while in class. The model lecturer becomes more focused on the learning process of students in the class and how to manage the class. The discussion session at the See stage helps the model lecturer to evaluate and criticize teaching after the learning process and as input for the next class planning strategy. Observer lecturers also gain valuable experience from the implementation of this program, where 
they can exchange and increase knowledge and experience on how to manage classes. Model and observer lecturers experience become broader in terms of classroom management and student characteristics understanding.

\section{Discussions}

\subsection{Implementation of Lesson Study}

Based on Lewis Lesson Study Cycle [7], there are several stages that are not fulfilled properly. In Plan activities, the lesson group are not functioning optimally. Ideally, the group functions as process control and idea sharing, the goal of conducting lesson studies, and to share the experiments with each other. In the implementation, the model lecturer and observer only discussed once for this stage with limited time. More discussion to confirm the model lecturer's lesson plans to observer lecturers. In addition, the experience and knowledge of lecturers in the SCL approach and blended learning are also lacking. The selection of courses used as a case study class was decided entirely by the model lecturer, so there was not much observer lecturer involvement in developing the material. The planning that was carried out was also not at the level of the long-term goals, only limited to the activeness and results of the discussion material at that meeting.

In the Do activity, the observer lecturer collects data from phenomena that occur in class, but in the first cycle, the observer lecturer is less than optimal in conducting observations in class. The observer lecturer is still fixated on the lecturer's performance when teaching alone. The data collected by them were also just field notes form, without any plan what they should be focused on in the lesson study process.

In the See activity, the model lecturer and observer should ideally consolidate what can be learned (about the subject matter, students' thinking instruction, and other facets), summarize in a presentation or in writing, and discuss what worked well in the model lecturer lesson study process and what model lecturer would like to change next time around [7]. However, in the implementation, the discussion in See stage is limited to describe the phenomena that occur without further discussion about why this happened.

\subsection{Implementation of the SCL approach, Flipped Classroom, and Edmodo}

Based on the results in the field, the selection of SCL, flipped classroom, and Edmodo as an approach in the lesson study is very helpful for lecturers in improving learning motivation, understanding of knowledge, and positive attitude of students towards the material being taught. The indications include: 1) The atmosphere of lectures coming alive is shown by the increased activity and self-confidence of students in constructing an understanding of lecture material and arguing in class; (2) The number of students not doing Edmodo assignments decreases from cycles 1 to 3; (3) Class settings with U-formations help to create a more conducive classroom atmosphere; and (4) The use of Edmodo really helps lecturers carry out learning using the flip classroom approach and SCL.

\section{Conclusion}

Based on the result and discussions, the implementation of lesson study that if the theory of Lewis was to become the standard of the rule, the lesson study implementation was not fulfilled well. There are several stages that are not fulfilled properly. In Plan activities, the lesson group are not functioning optimally. In the Do activity, the observer lecturer is still fixated on the lecturer's teaching performance. In the See activity, the conversation is limited to explain the phenomena that occur without further discussion about why this happened. While on the selection of SCL, flipped classroom, and Edmodo as an approach in the lesson study is very helpful for lecturers in improving learning motivation, understanding of knowledge, and positive attitude of students towards the material being taught. 


\section{Acknowledgment}

We would like to thank our parents, family, and friends.

\section{References}

1. Program Studi Sarjana Desain Komunikasi Visual ITB. Program Studi Sarjana Desain Komunikasi Visual [Internet]. 2019. Available from: https://www.itb.ac.id/program-studisarjana-desain-komunikasi-visual

2. Ristekdikti. Pedoman Panduan Bimtek Dosen Kategori Lesson Study Tahun 2018 [Internet]. 2018. Available from: http://sumberdaya.ristekdikti.go.id/wp-content/uploads/2018/03/PanduanBimtek-Lesson-Study-Tahun-2018.pdf

3. Rejeki S, Humaira, Maryani S, Nizar. Lesson Study for Learning Community (LSLC): Pengalaman Berharga dalam Pengelolaan Pembelajaran secara Terbuka. Inopendas J Ilm Kependidikan [Internet]. 2018;1(1):54-60. Available from: https://jurnal.umk.ac.id/index.php/pendas/article/view/2318

4. Collins JW, O'Brien NP. The Greenwood Dictionary of Education [Internet]. Organization. London: Greenwood Press; 2003. 431 p. Available from: http://www.netlibrary.com

5. Ana C. Manfaat Edmodo bagi Siswa dalam Proses Belajar di Sekolah [Internet]. 2015. Available from: https://manfaat.co.id/manfaat-edmodo-bagi-siswa-dalam-proses-belajar-di-sekolah

6. Satrio PUD, Utami ADW. Peningkatan Self-Directed Learning Readiness Mahasiswa dalam Mata Kuliah Fotografi Dasar melalui Flipped Classroom dan ICT. HEJ (Home Econ Journal) [Internet].2018;1(2):32-9.Availablefrom:

https://journal.uny.ac.id/index.php/hej/article/view/23274

7. Lewis C, Chaterine, Hurd J. Lesson Study Step by Step. Hanover: Porsmouth. N.H.; 2011. 